\title{
Laboratory Tests for Efficient Nitrate Removal with Water-Washed Zero Valent Iron and the Associated Mixed Mediums
}

\author{
Fulin Li, Xuequn Chen, Caihong Liu*, Qinghua Guan, Yuying Yuan \\ Water Resources Research Institute of Shandong Province / Shandong Province Key Laboratory \\ of Water Resources and Environment, Jinan, China
}

Received: 22 January 2018

Accepted: 25 March 2018

\begin{abstract}
The acid pre-washing of zero valent iron for improving removal efficiency would deduce the secondary pollution in groundwater, and more fine particles of zero valent iron would reduce the permeability of aquifers. In order to better understand the approaches of nitrate removal, a series of laboratory experiments was conducted in this study. Batch tests showed that washed zero valent iron powder and activated carbon are more efficient for removing nitrate than cemarite and zeolite, similar with the acid pre-washing zero valent iron. X-ray diffraction phase analysis showed that a kind of oxide $\mathrm{Fe}_{3} \mathrm{O}_{4}$ generated on the surface of the washed iron powder particles, which is mixed with $\mathrm{Fe}_{2} \mathrm{O}_{3}$ and $\mathrm{FeO}$, is relatively loose and can improve the efficiency of nitrate removal. A continuous flow column system test showed that the coarse sand-zero valent iron mix (R1), the coarse sand-zero valent iron-activated carbon mix (R4), and the coarse sand-zero valent iron-sawdust mix (R5) are more effective for reducing nitrate than the coarse sand-activated carbon mix (R2) and the coarse sand-sawdust mix (R3). Components such as $\mathrm{NO}_{2}{ }^{-} \mathrm{N}$ and $\mathrm{NH}_{4}{ }^{+} \mathrm{N}$ would have environmental concerns as well. Further chemical analysis on the fluids from nitrate removal treatment indicates that R1 and R4 are the most effective and also environmentally friendly media for nitrate removal. This study showed that R1 and R4 media could be developed into a viable technology for the removal of nitrate in high concentration of polluted groundwater.
\end{abstract}

Keywords: nitrate removal, zero valent iron, batch test, column system, groundwater

\section{Introduction}

Nitrate contamination in groundwater has become an increasingly serious environmental problem, especially to the people living in underdeveloped countries where many still rely on groundwater for

*e-mail: caihongliu1988@sina.com drinking water [1]. Nitrate pollution is considered as a nonpoint source that results from agriculture runoff, nitrogenous fertilizers, animal manure, industrial and domestic wastewaters, septic systems waste, etc. [25]. The nitrate contamination of groundwater is hidden and irreversible, its spatial and temporal variation is great, and its removal from groundwater has been a great challenge to the environmental community [6]. So it is a hot and difficult topic in nitrate removal and 
groundwater remediation aspects [7-8]. At present, many active materials have been successfully applied to nitrate removal, especially in the PRB system, which is used to deal with the nitrate pollution in groundwater [9-13]. The zero-valent metals such as Fe, Al, Zn, and $\mathrm{Mg}$ have been frequently used for reducing nitrate anions $[9,14]$. Among these zero-valent metals, zerovalent iron possesses a great importance for this purpose because it possesses a high specific surface area, which leads to high surface reactivity [15-16]. The use of zero-valent iron $(\mathrm{Fe} 0)$ in the treatment of nitrate in groundwater has been studied [17-20]. Many factors were believed to affect the performance of zero-valent iron toward nitrate removal, and many studies have been conducted over the past decades [21-22]. $\mathrm{pH}$ is one of the most important characteristics of water that affects the rates of nitrate removal by zero-valent iron since $\mathrm{pH}$ greatly affects the rate of zero-valent iron corrosion [23-24]. Iron's intrinsic characteristics, especially particle size, has been identified as an important feature that influences the sequestration kinetics of nitrate by zero-valent iron. Some researchers use the nanoiron as reaction medium, as its surface area $\left(>31.4 \mathrm{~m}^{2} \cdot \mathrm{g}^{-1}\right)$ and surface activity $\left(25.8 \mathrm{~kJ} \cdot \mathrm{mol}^{-1}\right)$ are larger than colloidal iron and industrial iron powder, which increase the contact chance of iron and $\mathrm{NO}_{3}$. So the nitrate removal of nanoiron is better than colloidal iron and industrial iron powder [25-26]. Another factor is acid washing, one of the earliest examples used to pretreat virgin zero-valent iron and which can remove the passive oxide layer and thus increase the reduction rates in laboratory tests [27].

However, there are also some defects during the treatment process. On the one hand, acid washing could produce strongly acidic wastewater with a high concentration of iron ions, and could make the loss of iron mass, which could cause secondary pollution of groundwater. This limited the widespread use of nitrate removal using zero-valent iron to a certain extent. On the other hand, as the major issues including longterm reactivity, mobility, and possible eco toxicity of nZVI are still unanswered, and the high cost is another consideration issue, especially the nanoiron with catalyst and chemical stabling agent whose price up to 120 U.S. $\$ / \mathrm{kg}$ [28], therefore the nZVI could not be widely used for nitrate removal until these issues are resolved. So researches that combine the biological and chemical methods such as adding the activated carbon and sawdust to the iron powder to remove the nitrate in groundwater were conducted.

This study discussed the feasibility and efficiency of nitrate removal by using the water-washed iron powder in comparison with other mediums. It was also discussed that the removal efficiency and the associated permeability of the mixed mediums, which include iron powder and adding other mediums in the near-neutral $\mathrm{pH}$ conditions in the field. The target was to improve the reaction efficiency and at the same time avoid the secondary pollution of groundwater. The objectives of this study were to: 1) select the suitable industrial iron powder for nitrate removal through batch experiments, 2) compare the nitrate removal efficiency of acid prewashed and water pre-washed of pristine ZVI, and 3) select the best composition mediums based on industrial iron powder through continuous flow column systems for nitrate removal under field conditions.

\section{Material and Methods}

\section{Materials}

Groundwater samples contaminated with nitrate were replaced by nitrate solution, which was prepared in the laboratory by dissolving a predetermined amount of $\mathrm{KNO}_{3}$ in the distilled water.

Zero-valent iron $\left(\mathrm{Fe}^{0}\right)$ with particle sizes of $250 \mu \mathrm{m}$, $420 \mu \mathrm{m}$, and $840 \mu \mathrm{m}$, activated carbon, cemarite, and zeolite with particle sizes of $0.3-0.8 \mathrm{~mm}$ were used as the reaction mediums, respectively. Quartz sand was used as aquifer media.

\section{Apparatus and Methods}

\section{Batch Experiments}

Laboratory-scale batch experiments and continuous flow column systems experiments were conducted to evaluate nitrate reduction by different reaction mediums. Batch experiments were used to evaluate the nitrate removal efficiency in different residence

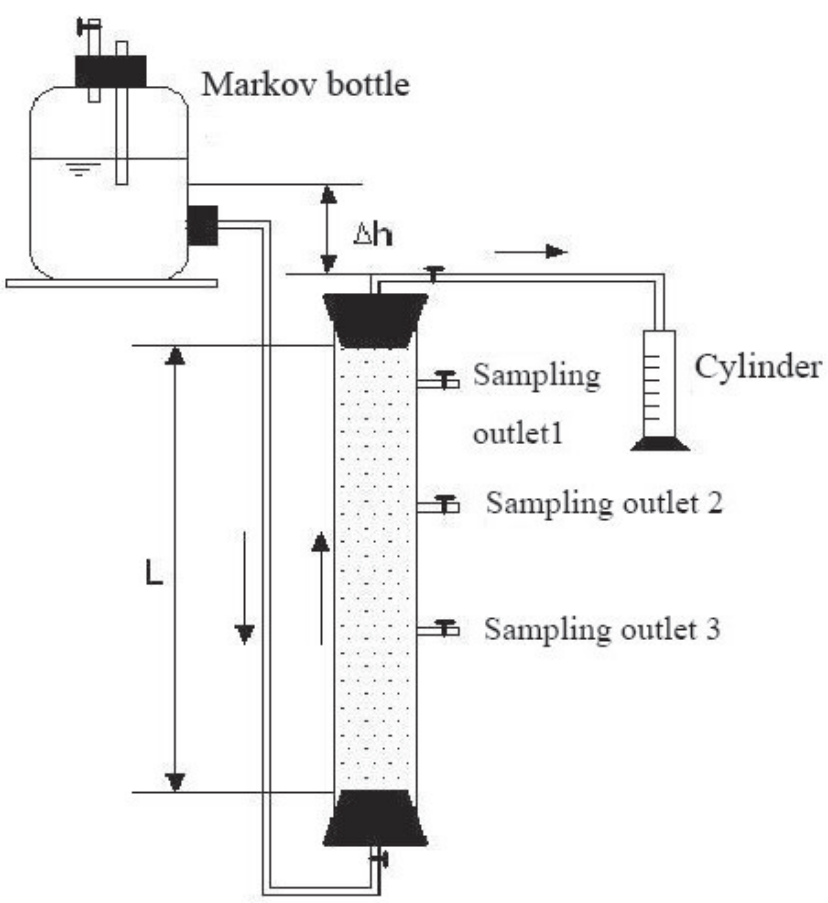

Fig. 1 The apparatus of the continuous flow column systems experiments. 

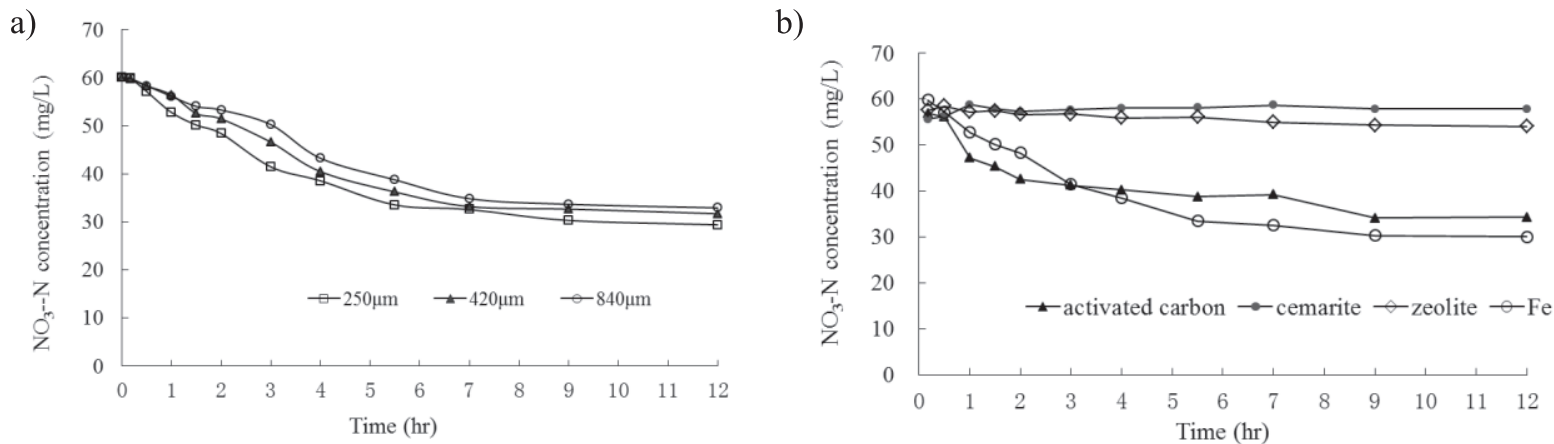

Fig. 2 Nitrate reduction by different particle size iron powder and different reaction mediums.

times. Jars were used as the reaction vessel containing the nitrate solution and the reaction mediums. When the reaction was complete, the variation of nitrate concentration and nitrate removal efficiency by iron powder were analyzed.

\section{Continuous Flow Column Systems Experiments}

As shown in Fig. 1, the reactor mediums were put in a cylindrical reactor with the length of $500 \mathrm{~mm}$ and internal diameter of $50 \mathrm{~mm}$, and the nitrate solution was put in an $11 \mathrm{~L}$ Markov bottle. The glass tube with internal diameter of $9 \mathrm{~mm}$ connecting the cylindrical reactor and the Markov bottle ensured a steady and continuous flow and kept the constant head difference $\Delta \mathrm{h}$ between the Markov bottle and the outlet of the cylindrical reactor. The nitrate solution outflowed from the Markov bottle to the bottom of the cylindrical reactor. After reaction in the reactor, the solution flowed from the top of the cylinder and into the measuring cylinder. In the outlet, there was $5 \mathrm{~cm}$ thick quartz sand to be the supporting layer to ensure continuous flow. Three sampling ports were set on the side of the cylindrical reactor.

Nitrate-N, nitrite- $\mathrm{N}$, and ammonia-N were measured by standard colorimetric method using a spectrophotometer (UV757). $\mathrm{pH}$ was monitored by the $\mathrm{pH}$ meter (PHSJ-5). A scanning electron microscope (SEM, Hitachi S-450) was used to obtain the microstructure and size information of iron powder.

\section{Results and Discussion}

\section{Batch Experiments in Single Medium \\ Nitrate Removal Efficiencies of Different Reaction Mediums}

The batch experiments were conducted in jars at $25^{\circ} \mathrm{C}$. The initial concentration of nitrate solution was $60 \mathrm{mg} / \mathrm{L}$ and the initial $\mathrm{pH}$ was 7. The reaction mediums were put into the nitrate solution in the jars and then put them in the oscillator at $200 \mathrm{r} / \mathrm{min}$.

Fig. 2 shows the nitrate concentration variations with time in different reaction mediums. The nitrate removal efficiency of different particle sizes iron powder is shown in Fig. 2a). The nitrate concentration decreased with time in all the particle size iron powders. The nitrate concentration decreased from $60 \mathrm{mg} / \mathrm{L}$ to $32.92 \mathrm{mg} / \mathrm{L}$, $31.71 \mathrm{mg} / \mathrm{L}$, and $29.40 \mathrm{mg} / \mathrm{L}$, and the removal rates were $45 \%, 47 \%$, and $51 \%$ in 12 hours when the iron powder particle sizes were $840 \mu \mathrm{m}, 420 \mu \mathrm{m}$, and $250 \mu \mathrm{m}$, respectively. The nitrate removal rate increased with the decrease of iron particle size as a whole. However, there was no significant difference among these three particle sizes, so we could think the nitrate removal efficiency of the three particle size iron powders was almost the same within half a day.

As shown in Fig. 2b), the $\mathrm{NO}_{3}^{-}$concentration gradually decreased with the increased reaction time in activated carbon and $\mathrm{Fe}^{0}$ mediums, while in the cemarite and zeolite mediums there was almost no variation. In the activated carbon medium and $\mathrm{Fe}^{0}$ medium, the $\mathrm{NO}_{3}^{-}$ concentration decreased from $60 \mathrm{mg} / \mathrm{L}$ to $34.34 \mathrm{mg} / \mathrm{L}$ and $30.12 \mathrm{mg} / \mathrm{L}$ in 12 hours, respectively. Therefore, the nitrate removal efficiency of activated carbon and $\mathrm{Fe}^{0}$ medium was better than for the cemarite and zeolite mediums.

\section{Nitrate Removal Efficiency under Different pH Conditions}

As there was oxide film on the surface of the iron powder, it would influence the nitrate removal efficiency. The removal rate would increase after treatment by acid. However, this would increase the secondary pollution. Therefore, washing and acid treatment efficiencies on iron powder were compared through batch experiments.

As shown in Fig. 3, at the same treatment time the nitrate concentration decreased with $\mathrm{pH}$ decreasing, which showed that the stronger the acidity, the better the nitrate removal efficiency by iron powder.

Fig. 4 presents the nitrate concentration variation in water pre-washed and acid pre-washed. The nitrate removal efficiency by water-washed iron powder was basically the same as that by acid washing when $\mathrm{pH}=4.0$. This shows that the pretreatment of ZVI by acid washing could be replaced by water washing, which could avoid the secondary pollution. 


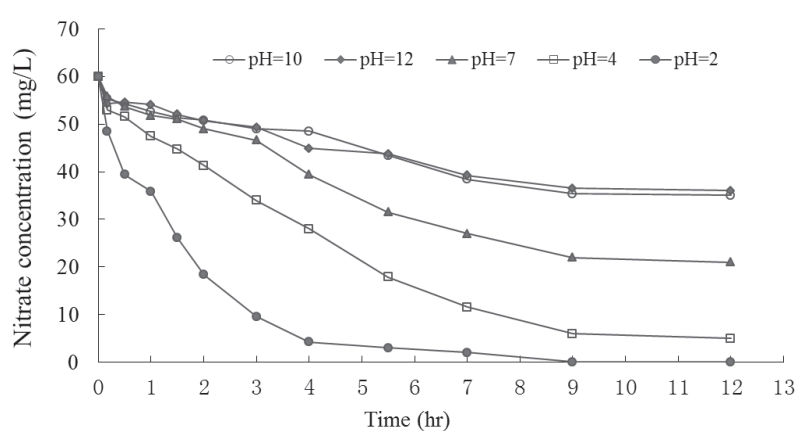

Fig. 3 Effect of $\mathrm{pH}$ on nitrate removal.

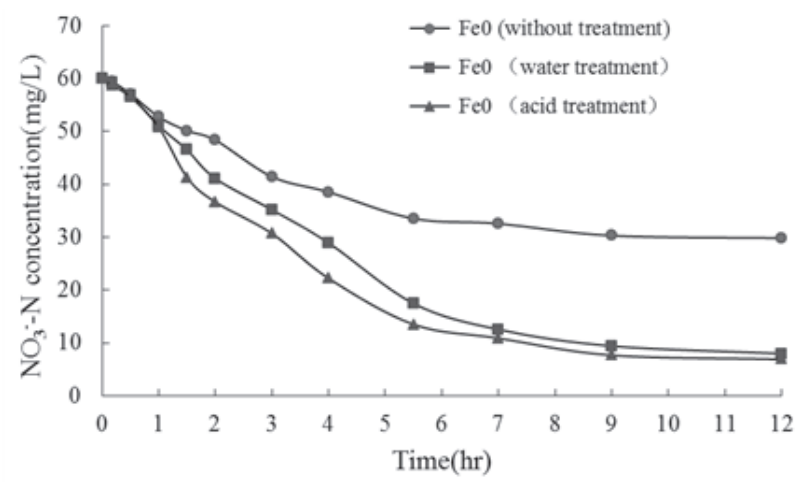

Fig. 4 The nitrate reduction by iron powder without treatment, washing by water and acid.

\section{Analysis of Surface Morphology and Structure of Iron Powder}

In order to further analyze the difference of the nitrate removal efficiency between iron powder before treatments and washing by water or acid, the surface morphology was observed by scanning electronic microscope and the material structure was tested and analyzed using x-ray diffraction (XRD).

Fig. 5 is the camera captured image and scanning electronic microscope (SEM) image of iron powder before and after treatments. As shown in Fig. 5a), the surface of $\mathrm{Fe}^{0}$ was relatively smooth and the structure was compact before washing by water. While after washing by water (Fig. 5b), there were a lot of micro pores on the surface of $\mathrm{Fe}^{0}$ and the structure was loose. In addition, the specific surface area increased, which increased the contact frequency of iron powder and $\mathrm{NO}_{3}$. Therefore, the nitrate removal of the iron powder after water washing was much more efficient than without washing.

$\mathrm{X}$-ray diffraction (XRD) analyses were performed to characterize mineralogical properties of $\mathrm{Fe}^{0}$ before and after the treatment (Fig. 6). XRD spectrum of iron powder before water washing showed 4 peaks corresponding to ferrite (Fig. 6a). Fig. 6b) showed the XRD spectrum of iron powder after water washing. It showed 11 peaks in the XRD spectrum analysis, of which the peak value was $3.021 \mathrm{cps}$. The main item on the sample surface was black grey magnetite with a proportion of $5.15 \mathrm{~g} / \mathrm{cm}^{3}$, while inside it was mainly pure iron powder. This indicated that the surface of the iron powder particles was oxidized to loose $\mathrm{MOX}$ of $\mathrm{Fe}_{2} \mathrm{O}_{3}$ and $\mathrm{FeO}$, which could improve the removal efficiency of nitrate. a)
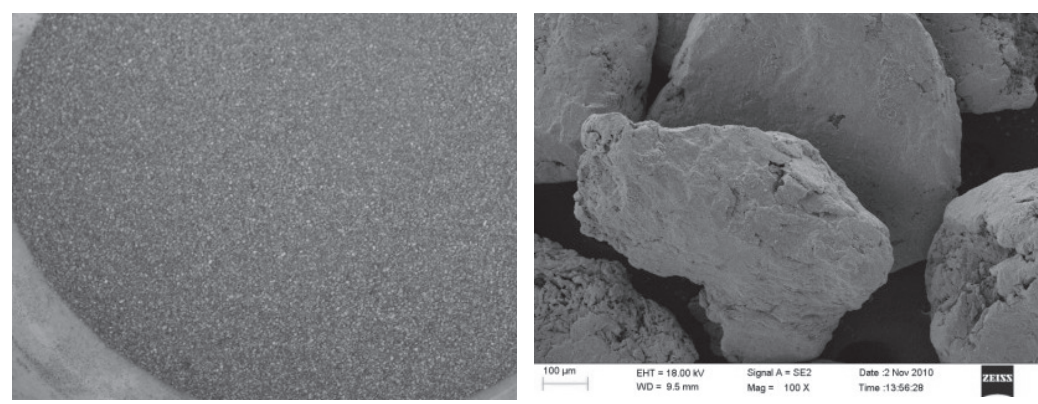

b)
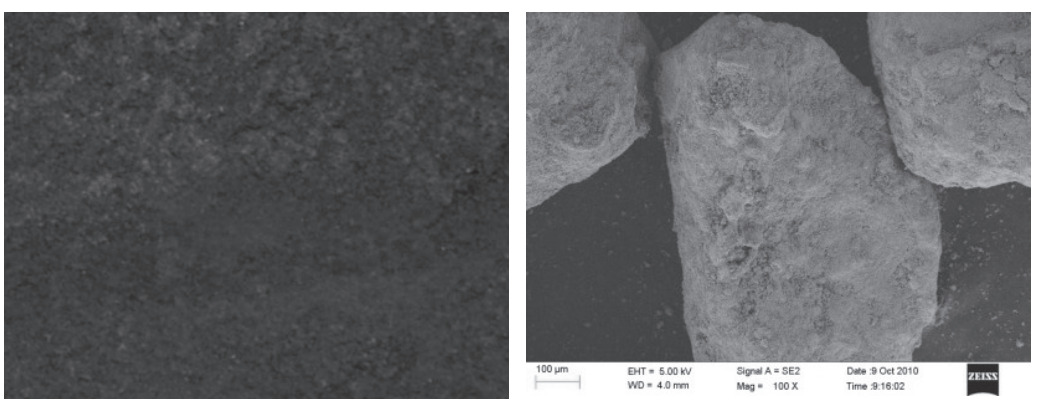
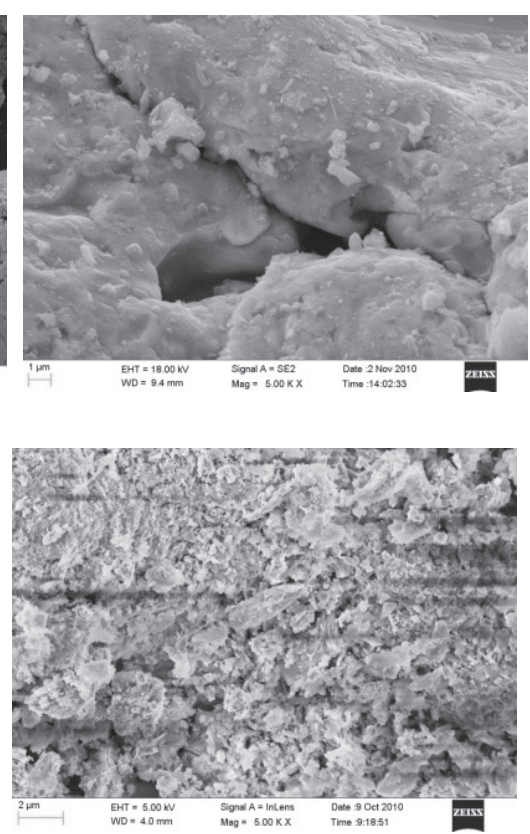

Fig. $5 \mathrm{SEM}$ images of $\mathrm{Fe}^{0}$ a) without pre-treatment and b) after washing by water. 
a)

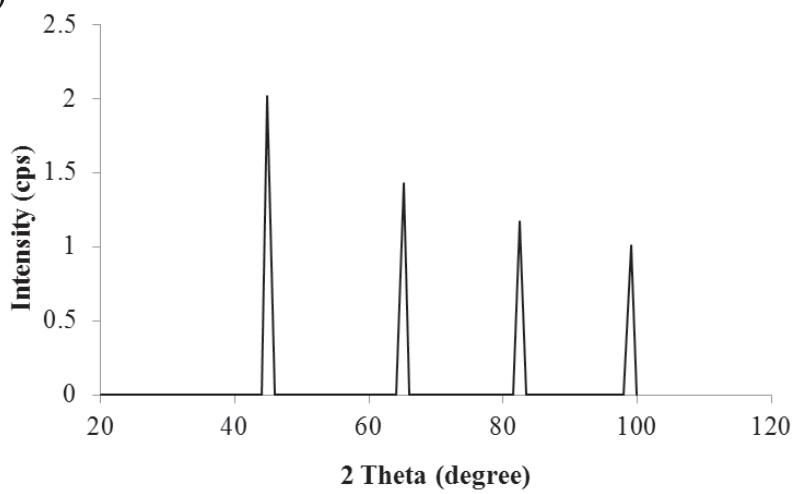

b)

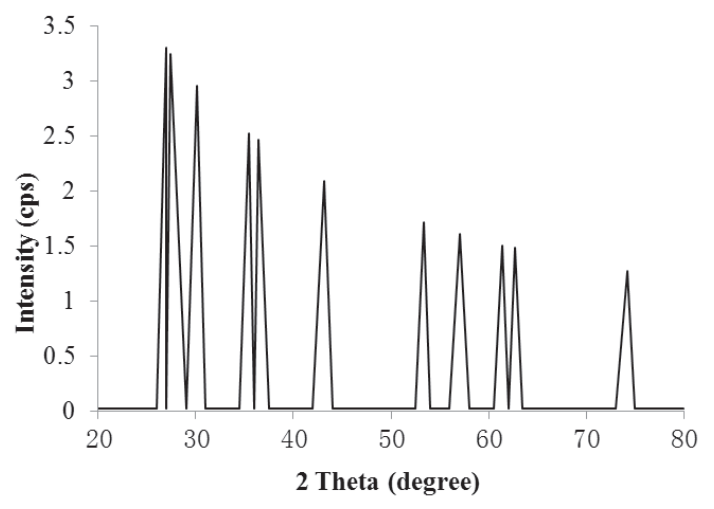

Fig. 6. X-ray diffraction patterns of $\mathrm{Fe}^{0}$ before and after treatment: a) before treatment, b) after treatment.

\section{Composite Mediums Cylinder Experiments near Field Conditions}

\section{Nitrate Removal Efficiency of Composite Mediums}

According to the batch experiment results, the nitrate removal efficiency of activated carbon and $\mathrm{Fe}^{0}$ mediums was better. However, when PRB for remediation of contaminated groundwater in the field, if the permeability of the reaction mediums was lower than the sandy aquifer, the groundwater would not pass through the PRB, which could not reach the effect of nitrate removal. So iron powder mixed with coarse sand and activated carbon would be a better choice as it could improve permeability and promote reaction. The initial concentration and $\mathrm{pH}$ of the nitrate solution in the Column system experiments was $80 \mathrm{mg} / \mathrm{L}$ and 7.0, respectively. Coarse sand-zero valent iron mix (R1), coarse sand-activated carbon mix (R2), coarse

Table 1. The experiments scheme of different composite mediums.

\begin{tabular}{|c|c|c|c|}
\hline $\begin{array}{c}\text { Test } \\
\text { scheme }\end{array}$ & $\begin{array}{c}\text { Medium } \\
\text { component }\end{array}$ & $\begin{array}{c}\text { Particle } \\
\text { size/mm }\end{array}$ & $\begin{array}{c}\text { percent } \\
/ \%\end{array}$ \\
\hline \multirow{2}{*}{ R1 } & Coarse sand & $0.25-2.0$ & 70 \\
\cline { 2 - 4 } & Iron powder & $0.25-0.5$ & 30 \\
\hline \multirow{2}{*}{ R2 } & Coarse sand & $0.25-2.0$ & 70 \\
\cline { 2 - 4 } & Activated carbon & $0.3-3.0$ & 30 \\
\hline \multirow{3}{*}{ R3 } & Coarse sand & $0.25-2.0$ & 70 \\
\cline { 2 - 4 } & Sawdust & $0.25-2.0$ & 30 \\
\hline \multirow{3}{*}{ R4 } & Coarse sand & $0.25-2.0$ & 40 \\
\cline { 2 - 4 } & Iron powder & $0.25-0.5$ & 30 \\
\cline { 2 - 4 } & Activated carbon & $0.3-3.0$ & 30 \\
\hline \multirow{3}{*}{ R5 } & Coarse sand & $0.25-2.0$ & 40 \\
\cline { 2 - 4 } & Iron powder & $0.25-0.5$ & 30 \\
\cline { 2 - 4 } & Sawdust & $0.25-2.0$ & 30 \\
\hline
\end{tabular}

sand-sawdust mix (R3), coarse sand-zero valent ironactivated carbon mix (R4), and coarse sand-zero valent iron-sawdust mix (R5) media were tested (Table 1). The hydraulic conductivity of the composite media was about $52 \mathrm{~m} / \mathrm{d}$. the nitrate concentration variation with time is shown in Fig. 7.

From Fig. 7 we see that there were obvious differences in the effects of different composite media on nitrate removal. In two-phase mixed medium the nitrate removal efficiency of R1 was best. The nitrate concentration dropped rapidly from $80 \mathrm{mg} / \mathrm{L}$ to less than $10 \mathrm{mg} / \mathrm{L}$ within 24 hours. For R 2 composite media, the nitrate concentration decreased rapidly in the first day, and then gradually increased, which indicated that the activated carbon had a certain physical adsorption effect on nitrate and the activated carbon would lose its effect when it reached saturation. For R3 sawdust/ coarse sand mix, the nitrate concentration decreased linearly. The nitrate removal rate of three-phase mixed medium (R4 and R5) was better than two-phase mixed medium, which the concentration of nitrate decreased less than $10 \mathrm{mg} / \mathrm{L}$ in 24 hours. Comparing the removal results of R4, R5, and R1, the nitrate concentration of

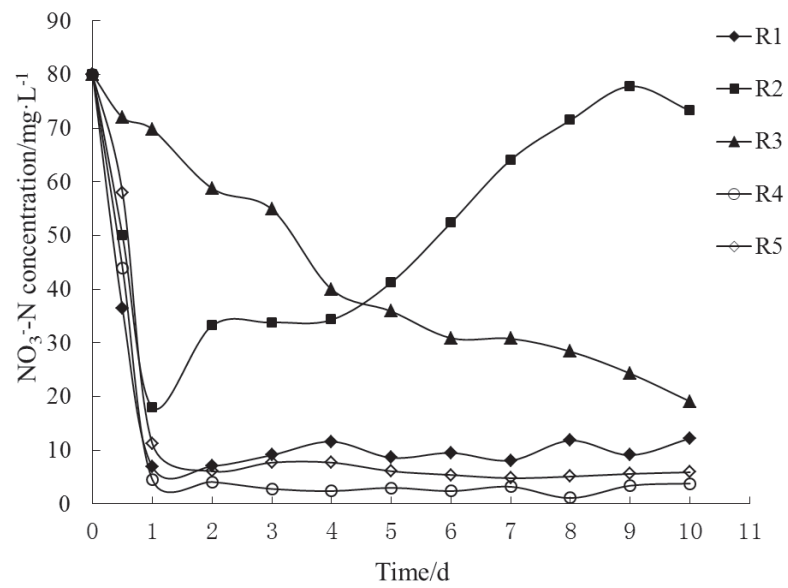

Fig. 7 The nitrate reduction across laboratory columns with different composite mediums. 
a)

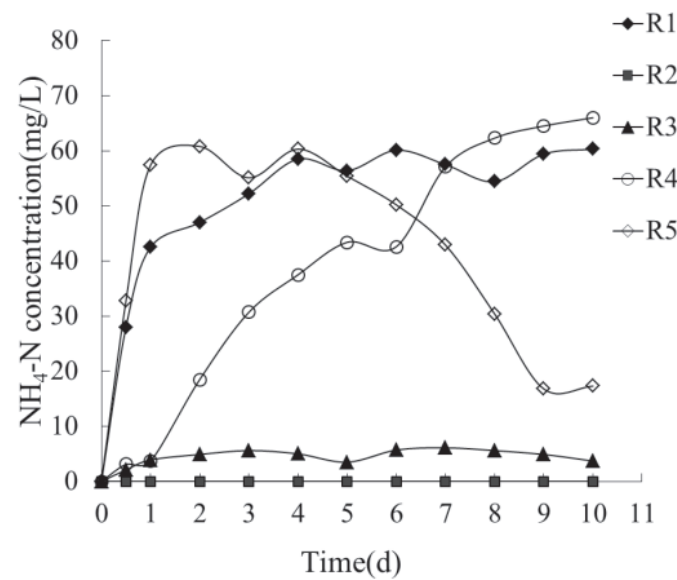

b) 12

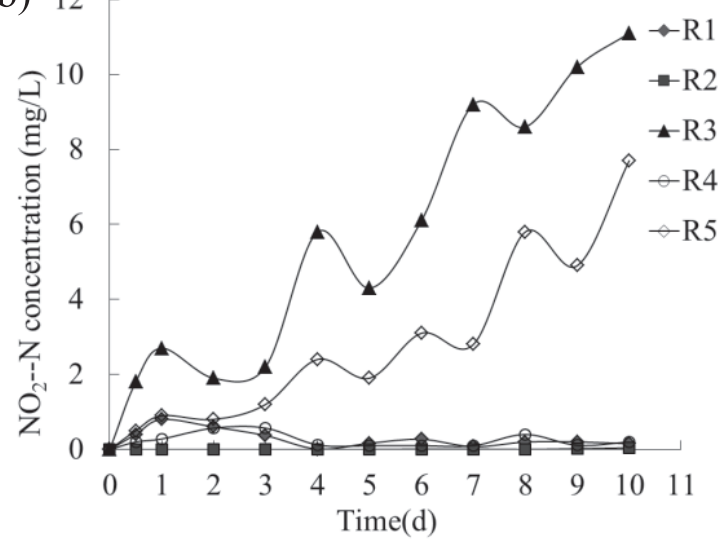

Fig. 8 The $\mathrm{NH}_{4}^{+}-\mathrm{N}$ and $\mathrm{NO}_{2}-\mathrm{N}$ produced from laboratory columns with different composite mediums: a) $\mathrm{NH}_{4}^{+}-\mathrm{N}$ concentration, b) $\mathrm{NO}_{2}-\mathrm{N}$ concentration.

$\mathrm{R} 4$ and R5 reactive medium was a bit lower than R1, which showed that coupling ZVI with activated carbon and with sawdust were better for nitrate removal.

\section{Analysis of Intermediate Chemical Products}

The nitrate removal process was a chemical reaction process. The ideal target is generating non-toxic and tasteless gas elements $\mathrm{N}_{2}$ during the process of nitrate removal. However, the reaction process is very complex, with some intermediate products such as $\mathrm{NO}_{2}-\mathrm{N}$ and $\mathrm{NH}_{4}^{+}-\mathrm{N}$ being generated in the reaction process. When using sawdust as reaction media to remove nitrate, the sawdust could provide a carbon source for heterotrophic microorganisms, which could promote denitrification. Nitrate was converted to $\mathrm{N}_{2} \mathrm{O}$ or $\mathrm{N}_{2}$ under the action of denitrification bacteria (Fig. 8).

From Fig. 8 , no $\mathrm{NH}_{4}^{+}-\mathrm{N}$ produced in the coarse sand/AC mix medium (R2), and less than $6 \mathrm{mg} / \mathrm{L}$ $\mathrm{NH}_{4}^{+}-\mathrm{N}$ was produced in coarse sand/sawdust mix medium (R3). In R1, R4, and R5 composite mediums, there was large $\mathrm{NH}_{4}^{+}-\mathrm{N}$ generation. There was a little $\mathrm{NO}_{2}{ }^{-} \mathrm{N}$ generated in $\mathrm{R} 1, \mathrm{R} 2$, and $\mathrm{R} 4$ composite mediums; however, in R3 and R5, there was large $\mathrm{NO}_{2}-\mathrm{N}$ generation. So, the reduction product of $\mathrm{NO}_{3}{ }^{-}$ is mainly $\mathrm{NH}_{4}^{+}-\mathrm{N}$ in coarse sand/ZVI mix medium (R1), and $\mathrm{NO}_{2}^{-} \mathrm{N}$ is the main reduction product in coarse sand/sawdust mix medium (R3). For R2 reactive medium, there was little by way of reduction products. If the concentration of the reduction products was larger than the drinking water standard $\left(\mathrm{NH}_{4}^{+}: 0.2 \mathrm{mg} / \mathrm{L}\right.$, $\mathrm{NO}_{2}{ }^{-}: 0.066 \mathrm{mg} / \mathrm{L}$ ), they need further processing. The treatment of ammonia nitrogen is relatively easy, while it is difficult for $\mathrm{NO}_{2}-\mathrm{N}$ processing.

In all the mix mediums, the $\mathrm{NO}_{3}^{-}$removal rate of coarse sand/ZVI mix medium (R1) and coarse sand/ ZVI/AC mix medium (R4) was better, and the reduction product was mainly $\mathrm{NH}_{4}^{+}-\mathrm{N}$, so $\mathrm{R} 1$ and $\mathrm{R} 4$ are the best PRB mix medium for nitrate pollution remediation.

\section{Discussions}

The reduction of nitrate by iron powder is a high exothermic and spontaneous chemical reaction process. The main reactions involved in the production and consumption of $\mathrm{NO}_{2}$ anion are the following:

$$
\begin{gathered}
5 \mathrm{Fe}^{0}+2 \mathrm{NO}_{3}^{-}+12 \mathrm{H}^{+} \rightarrow \mathrm{N}_{2}+5 \mathrm{Fe}^{2+}+6 \mathrm{H}_{2} \mathrm{O} \\
4 \mathrm{Fe}^{0}+\mathrm{NO}_{3}^{-}+10 \mathrm{H}^{+} \rightarrow 4 \mathrm{Fe}^{2+}+\mathrm{NH}_{4}^{+}+3 \mathrm{H}_{2} \mathrm{O} \\
\mathrm{Fe}^{0}+\mathrm{NO}_{3}^{-}+2 \mathrm{H}^{+} \rightarrow \mathrm{NO}_{2}^{-}+\mathrm{Fe}^{2+}+\mathrm{H}_{2} \mathrm{O}^{-} \\
3 \mathrm{Fe}^{0}+\mathrm{NO}_{2}^{-}+8 \mathrm{H}^{+} \rightarrow 3 \mathrm{Fe}^{2+}+\mathrm{NH}_{4}^{+}+2 \mathrm{H}_{2} \mathrm{O}
\end{gathered}
$$

During the process, the by-products $\mathrm{Fe}^{2+}$ and Fe $(\mathrm{OH})^{+}$could also react with $\mathrm{NO}_{3}^{-}$, in which case the reactions are as following:

$$
\begin{gathered}
8 \mathrm{Fe}^{2+}+\mathrm{NO}_{3}^{-}+13 \mathrm{H}_{2} \mathrm{O} \rightarrow 8 \mathrm{FeOOH}+\mathrm{NH}_{4}^{+}+14 \mathrm{H}^{+} \\
8 \mathrm{Fe}^{2+}+2 \mathrm{NO}_{3}{ }^{-}+11 \mathrm{H}_{2} \mathrm{O} \rightarrow 8 \mathrm{FeOOH}+\mathrm{N}_{2} \mathrm{O} \uparrow+14 \mathrm{H}^{+} \\
10 \mathrm{Fe}^{2+}+2 \mathrm{NO}_{3}{ }^{-}+14 \mathrm{H}_{2} \mathrm{O} \rightarrow 10 \mathrm{FeOOH}+\mathrm{N}_{2} \uparrow+8 \mathrm{H}^{+} \\
12 \mathrm{Fe}^{2+}+\mathrm{NO}_{3}^{-}+13 \mathrm{H}_{2} \mathrm{O} \rightarrow 4 \mathrm{Fe}_{3} \mathrm{O}_{4}+\mathrm{NH}_{4}^{+}+22 \mathrm{H}^{+} \\
12 \mathrm{Fe}(\mathrm{OH})^{+}+\mathrm{NO}_{3}^{-}+\mathrm{H}_{2} \mathrm{O} \rightarrow 4 \mathrm{Fe}_{3} \mathrm{O}_{4}+\mathrm{NH}_{4}^{+}+10 \mathrm{H}^{+}
\end{gathered}
$$

It can be seen from the reaction equations that both $\mathrm{Fe}^{2}$ and $\mathrm{Fe}^{0}$ can react with $\mathrm{NO}_{3}^{-}$. The oxide $\mathrm{Fe}_{3} \mathrm{O}_{4}$ generated on the surface of the iron powder washing by water and acid was the MOX of $\mathrm{Fe}_{2} \mathrm{O}_{3}$ and $\mathrm{FeO}$, which indicated that $\mathrm{Fe}^{2+}$ was generated when the iron powder was washed by water and acid. Washing by water and acid accelerated the reaction process, and then the nitrate removal rate was also accelerated. This is the fundamental cause that the nitrate removal rate was better when the iron powder was washed by water or acid. 
The ideal target is generating intermediate nontoxic and tasteless gas elements $\mathrm{N}_{2}$ during the process of nitrate removal. However, the products including $\mathrm{NO}_{2}-\mathrm{N}$ and $\mathrm{NH}_{4}^{+}-\mathrm{N}$ were generated in the reaction process when the reaction mediums were iron powder and sawdust, of which the concentration exceeded the drinking water quality standards. So the water after treatments still influence drinking and need to be treated further. This is one of the limiting conditions that makes $\mathrm{Fe}^{0}$ difficult to be widely used in nitrate removal of groundwater.

Although adding coarse sand to $\mathrm{Fe}^{0}$ to improve the permeability of the reaction media, it is difficult to keep both permeability and reaction efficiency. Therefore, it is necessary to carry out field experiments and numerical simulation to analyze the application effect.

\section{Conclusions}

1) Through the batch experiments of different reaction media, including industrial iron powder, activated carbon, cemarite, and zeolite, the industrial iron powder and activated carbon could be well media for nitrate removal as they had better efficiency in removing the nitrate.

2) The stronger acid environments, the better the nitrate removal efficiency by iron powder. The removal efficiency of the iron powder washing by water was still well, and in the meanwhile washing by water could avoid the secondary pollution, which indicated that water washing iron powder would be a good choice.

3) Adding coarse sand and activated carbon to iron powder could improve the permeability of the reaction media and meanwhile not lose its reaction efficiency. The study results implied that it has important guiding significance to use $\mathrm{Fe}^{0}$-based PRB for in situ remediation of nitrate contamination in the field.

\section{Acknowledgements}

The authors would like to thank the Technical Demonstration Project of Ministry of Water Resources of China (NO.SF-201624) and the National- International Science and Technology Cooperation Project of China (2012DFG22140)for financially supporting this research.

\section{Conflict of Interest}

The authors declare no conflict of interest.

\section{References}

1. MIOTLINSKI K. Coupled reactive transport modeling of redox processes in a nitrate-polluted sandy aquifer. Aquat Geochem. 14, 117, 2008.

2. SNYDER C.S., BRUULSEMA T.W., JENSEN T.L., FIXEN P.E. Review of greenhouse gas emissions from crop production systems and fertilizer management effects. Agric. Ecosyst. Environ. 133, 247, 2009.

3. GU B., GE Y., CHANG S.X., LUO W., CHANG J. Nitrate in groundwater of china: sources and driving forces. Global Environmental Change. 23 (5), 1112, 2013.

4. AHMED M.E. KHALIL, OSAMA ELJAMAL, SKANDER JRIBI, NOBUHIRO MATSUNAG Promoting nitrate reduction kinetics by nanoscale zero valent iron in water via copper salt addition. Chemical Engineering Journal. 287, 367, 2016.

5. BIAN J.M., LIU C.H., ZHANG Z.Z., WANG R., GAO Y. Hydro-Geochemical Characteristics and Health Risk Evaluation of Nitrate in Groundwater. Pol. J. Environ. Stud. 25 (2), 521, 2016.

6. DHONDT K., BOECKX P., VERHOEST N.E.C., HOFMAN G., CLEEMPUT O.V. Assessment of temporal and spatial variation of nitrate removal in riparian zones. Environmental Monitoring and Assement. 116, 197, 2006.

7. DONG-WAN C., HOCHEOL S., SCHWARTZ F.W., BOKSEONG K., BYONG-HUN J. The role of magnetite nanoparticles in the reduction of nitrate in groundwater by zero-valent iron. Chemosphere. 125, 41, 2015.

8. ALLISON M. BERGQUIST, JONG KWON CHOE, TIMOTHY J. STRATHMANN, CHARLES J. WERTH Evaluation of a hybrid ion exchange-catalyst treatment technology for nitrate removal from drinking water. Water Research. 96, 177, 2016.

9. LAPOINTE F., FYTAS K., MCCONCHIE D. Efficiency of bauxsol ${ }^{\mathrm{TM}}$ in permeable reactive barriers to treat acid rock drainage. Mine Water and the Environment. 25, 37, 2006.

10. LEE J.Y., LEE K.J., SUN Y.Y., LEE M.R., KAMALAKANNAN S., OH B.T. Stability of Multi-Permeable Reactive Barriers for Long Term Removal of Mixed Contaminants. Bull Environ Contam Toxicol. 84, 250, 2010.

11. ZHANG Y., ANGELIDAKI I. A new method for in situ nitrate removal from groundwater using submerged microbial desalination-denitrification cell (SMDDC). Water Research. 47 (5), 1827, 2013.

12. LI R., FENG C., CHEN N., ZHANG B., HAO C., PENG T. A bench-scale denitrification wall for simulating the in-situ treatment of nitrate-contaminated groundwater. Ecological Engineering. 73, 536,2014.

13. KIM M.S., LEE D.W., CHUNG S.H., JI T.K., CHO I.H., LEE K.Y. Pd-Cu bimetallic catalysts supported on $\mathrm{TiO}_{2}-\mathrm{CeO}_{2}$ mixed oxides for aqueous nitrate reduction by hydrogen. Journal of Molecular Catalysis A: Chemical. 392, 308, 2014.

14. CHI I., ZHANG S.T., LU X., DONG L.H., YAO S.L. Chemical reduction of nitrate by metallic iron. J. Water Supply Res. Technol. 53 (1), 37, 2004.

15. FU F., DIONYSIOU D.D., LIU H. The use of zerovalent iron for groundwater remediation and wastewater treatment: A review. Journal of Hazardous Materials. 267, 194, 2014. 
16. SUN Y., LI J., HUANG T., GUAN X. The influences of iron characteristics, operating conditions and solution chemistry on contaminants removal by zero-valent iron: A review. Water Research. 100, 277, 2016.

17. SU C., PULS R.W. Nitrate reduction by zerovalent iron: effects of formate, oxalate, citrate, chloride, sulfate, borate, and phosphate. Environ. Sci. Technol. 38, 2715, 2004.

18. BUROW K.R., NOLAN B.T., RUPERT M.G., DUBROVSKY N.M. Nitrate in groundwater of the United States, 1991-2003. Environ. Sci. Technol. 44, 4988, 2010.

19. AHN Y.T., KIM H., CHO D.W., JEON B.H. Removal of nitrate from groundwater using ZVI treatment system combined with continuous $\mathrm{CO}_{2}$ gas bubbling. Geosyst. Eng. 15, 60, 2012.

20. ZHOU H.Y., LIANG S., ZENG S.S., LEI S.J. Chemical Reduction of Nitrate in Aqueous Solution by Iron Powder. Advanced Materials Research. 777, 71, 2013.

21. ALOWITZ M.J., SCHERER M.M. Kinetics of nitrate, nitrite, and $\mathrm{Cr}(\mathrm{VI})$ reduction by iron metal. Environ. Sci. Technol. 36 (3), 299, 2002.

22. TANG S., WANG X.M., MAO Y.Q., ZHAO Y., YANG H.W., XIE Y.F. Effect of dissolved oxygen concentration on iron efficiency: removal of three chloroacetic acids. Water Res. 73, 342, 2015.
23. BAE S., HANNA K. Reactivity of nanoscale zero-valent iron in unbuffered systems: effect of $\mathrm{pH}$ and $\mathrm{Fe}(\mathrm{II})$ dissolution. Environ. Sci. Technol. 49 (17), 10536, 2015.

24. O'CARROLL D., SLEEP B., KROL M., BOPARAI H., KOCUR C. Nanoscale zero valent iron and bimetallic particles for contaminated site remediation. Adv. Water Resour. 51, 104, 2013.

25. LIU Y., MAJETICH S.A., TILTON R.D., SHOLL D.S., LOWRY G.V. TCE dechlorination rates, pathways, and efficiency of nanoscale iron particles with different properties. Environmental Science and Technology. 39, 1338, 2005.

26. CHOE S., CHANG Y.Y., HWANG K.Y., KHIM J. Kinetics of reductive denitrification by nanoscale zero-valent iron. Chemosphere. 41 (8), 1307, 2000.

27. TANG C., ZHANG Z., SUN X. Effect of common ions on nitrate removal by zero-valent iron from alkaline soil. Journal of Hazardous Materials. 231-232, 114, 2012.

28. GANASKAR A., TATAR L., CONDIT W. Cost and Performance Report-Nanoscale Zero-valent Iron Technologies for Source Remediation, Naval Facilities Engineering Service Center, Contract Number. N4740801-D-8207,2005. 